\title{
The Acquisition and Commercialization of Invention in American Manufacturing: Incidence and Impact
}

\author{
Ashish Arora, ${ }^{1}$ Wesley M. Cohen ${ }^{2}$ and John P. Walsh ${ }^{3}$
}

\begin{abstract}
Recent accounts suggest the development and commercialization of invention has become more "open." Greater division of labor between inventors and innovators can enhance social welfare through gains from trade and greater economies of specialization. Moreover, this extensive reliance upon outside sources for invention also suggests that understanding the factors that condition the extramural supply of inventions to innovators is crucial to understanding the determinants of the rate and direction of innovative activity.

This paper reports on a recent survey of over 5000 American manufacturing sector firms on the extent to which innovators rely upon external sources of invention. Our results indicate that, between 2007 and 2009, 16\% of manufacturing firms had innovated - meaning had introduced a product that was new to the industry. Of these, $49 \%$ report that their most important new product had originated from an outside source, notably customers, suppliers and technology specialists (i.e., universities, independent inventors and R\&D contractors). We also compare the contribution of each source to innovation in the US economy. Although customers are the most frequent outside source, inventions acquired from technology specialists tend to be the more economically significant in term of their gross commercial value. As a group, external sources of invention make a significant contribution to the overall rate of innovation in the economy. Innovation policies, both public and private, should pay careful attention to the external supply of invention, and the efficiency of the mechanisms affecting the relationships between inventors and innovators.
\end{abstract}

Acknowledgements: This research was funded by grants from the National Science Foundation (grant \#0830349) and the Kauffman Foundation. Additional support was provided by The Fuqua School of Business, Duke University, The School of Public Policy, Georgia Tech and the National Institutes of Health (Award Number P50HG003391). You-Na Lee and Colleen Cunningham provided outstanding research assistance. We are also grateful to Vaibhav Gajulapalli and Arun Patro for helping with data construction, and to seminar participants at Carnegie Mellon, Columbia, Duke, Berkeley, Michigan, MIT, New York University, Toronto, University of North Carolina (Greensboro), Tilburg, KU Leuven, Cambridge, London Business School, Japan's Research Institute of Economy, Trade and Industry, the Roundtable for Engineering Entrepreneurship Research at Georgia Tech, the Atlanta Competitive Advantage Conference, the International Joseph A. Schumpeter Conference held in Jena, Germany and the $\mathrm{IP}^{2}$ Conference at the Hoover Institution for helpful comments. We are also grateful to Anthony Arundel for his assistance with the design of the survey instrument, and to two anonymous reviewers of this journal for many helpful comments and suggestions. The customary disclaimers apply.

KEYWORDS: innovation; division of innovative labor; external sourcing; technology specialists; startups; patent propensity

\footnotetext{
${ }^{1}$ Duke University and NBER, ashish.arora@duke.edu

${ }^{2}$ Duke University and NBER, wcohen@duke.edu

${ }^{3}$ Georgia Institute of Technology, john.walsh@pubpolicy.gatech.edu
} 


\section{The Acquisition and Commercialization of Invention in American Manufacturing: Incidence and Impact}

\section{Introduction}

Until recently, the dominant model of innovation conceived of the innovation process as typically carried out within the confines of a given firm, starting with the firm investing in R\&D to generate inventions, and then developing and commercializing those inventions. This model has become less accurate as a description of the innovation process over time to the degree that companies now commonly source inventions from the outside (Chesbrough, 2003). We lack, however, systematic evidence on the extent to which innovations introduced by US manufacturers rely upon external inventions.

Distinguishing between invention (i.e., discovery) and innovation (i.e., the commercialization of an invention), ${ }^{4}$ this paper presents results from a survey of over 5000 American manufacturing firms on the extent to which innovating firms obtain inventions from external sources. We first identify innovating firms, and then document the share of innovating firms that acquire their inventions from different sources as well as the channels through which firms acquire those inventions. We also characterize how the distribution of value from invention compares across different sources. Finally, we estimate the relationship between external sourcing of inventions and the rate of innovation in the manufacturing sector.

Why is our study of what Arora and Gambardella (1994) call the "division of innovative labor" important? The availability and use of external sources of invention may offer important social welfare benefits. First, there are social welfare gains from trade. When the firms best equipped to invent are not necessarily the firms most capable of commercializing invention, society benefits when an invention can transfer between them. Economic theory, starting with Adam Smith, further suggests that such a division of innovative labor should also confer systemwide efficiencies through economies of specialization.

In addition to the welfare implications of a division of innovative labor, our study offers implications for empirical scholars of technological change. For example, if reliance upon external sources of invention is pervasive, then an understanding of the factors affecting the

\footnotetext{
${ }^{4}$ Our distinction between invention and innovation follows Schumpeter's treatment (1939, p. 80).
} 
availability of those inventions should help us understand an industry's rate of innovation. Moreover, to the degree that firms in other industries are supplying these inventions, an understanding of an industry's innovative activity will need to extend beyond conventionally considered determinants of innovation applicable to the innovating firms' own industry (e.g., appropriability, market demand, and technological opportunity) to those applicable to the markets of the potential suppliers of invention.

A number of related literatures have already examined the links across firms and between firms and other institutions that contribute to innovative performance. One literature has focused on knowledge spillovers across rivals, as distinct from the purposeful sourcing of invention (e.g., Griliches, 1992). Other studies have focused on particular sources of inventions-including startups (e.g., Arora and Gambardella, 1990), universities (e.g., Klevorick et al., 1995; Henderson et al., 1998; Cohen et al., 2002), suppliers (Pavitt, 1984), and customers (e.g. von Hippel, 1986) — as important contributors to the innovations produced by firms.

Building upon Mueller (1962), Jewkes, Sawers and Stillerman (1969), Freeman (1991) and others, survey-based studies of the American manufacturing sector have considered a broad set of knowledge sources for innovative activities, such as buyers, suppliers and universities (Klevorick et al., 1995; Cohen et al., 2002a, 2002b). More recently, scholars using data gathered through the Community Innovation Survey (CIS) have also reported findings on the different sources contributing to firms' innovative activities in Europe. Examples of these studies include Tether (2002) for the UK, Veugelers and Cassiman (1999) for Belgium, Lhuillery and Pfister (2009) for France, and Belderbos et al (2004) for Netherlands. Mohnen and Roeller (2005) and Tether and Tajar (2008) are examples of studies that use cross-country CIS data.

Other studies have examined specific channels through which firms' benefit from extramural sources of knowledge, such as licensing (e.g., Arora and Gambardella, 1990; Arora et al., 2001) and collaboration (e.g., Hagedoorn, 2003; Tether, 2002; Laursen and Salter, 2006, 2014; Grimpe and Sofka, 2009, Sofka and Grimpe, 2010, Belderbos et al. 2004).

Our paper offers several advances. First, we report on the contribution of external sources to innovation in the U.S. manufacturing sector, as distinct from prior studies for the U.S. that focused on the contributions of external sources to R\&D per se (Klevorick et al., 1995; Cohen et al., 2002a, 2002b). Second, our survey is the first to focus on whether an innovating firm obtains 
the underlying invention from an outside source, unlike prior work that examined the importance of information flows from different sources or collaboration with external sources.

Unlike the prior literature, our survey focuses on the respondent's most important product innovation rather than the respondent's innovation activities in general. Inquiring about a specific innovation allows us to link the source of the invention to the channel employed, as well as to other activities and outcomes, including the percentage of sales due to a given innovation and whether the innovation is patented. We are also able to tie the specific innovation to activities to commercialize the innovation, including investment in equipment, hiring of new personnel, or the development of new distribution channels. Our data also permit us to compare the costs and benefits - and thus the value - of inventions from different sources by providing measures of the frequency with which inventions are obtained from a particular source, as well as indicators of value (e.g., the share of sales from the innovative product, whether it was patented, and whether the innovator made complementary investments).

To preview our findings, we find that, of the $16 \%$ of the U.S. manufacturing firms that innovated (i.e., had introduced a new or significantly improved product to the industry) between 2007 and 2009, 49\% report that their most important new product originated from an identified outside source, suggesting pervasive reliance upon external sources of invention. Just over a third of these transfers involves a market transaction, such as a license, a service contract or an equity purchase. We also find that, although customers are the most pervasive source of outside invention, those originating from what we call "technology specialists" - independent inventors, contractors and universities - tend to be more valuable. Finally, using two different analytic approaches, we conclude that denying firms the opportunity of going to an outside source could lead to a reduction of as much as $33 \%$ to $45 \%$ in the share of innovating firms in the U.S. manufacturing sector.

To motivate the study, section 2 offers a simple model to illustrate how external supply of inventions may affect innovation. In section 3, we describe the survey design underlying our sample. Section 4 presents our findings with respect to innovation rates, the sources of innovation, and the channels through which innovators acquire the inventions underlying their innovations. We also compare the relative cost and value of the inventions originating from different sources, and analyze the relationship between innovation rates and the extramural 
sourcing of invention. Section 5 summarizes our main findings, discusses the implications and concludes.

\section{Background}

If external sourcing of invention is pervasive, this has important implications for our understanding of the drivers of innovation. To motivate our empirical analysis, we offer a simple illustrative model to show that external sources do not simply affect the "make-or-buy" decision regarding $\mathrm{R} \& \mathrm{D}$, but whether to innovate at all. ${ }^{5}$

In Figure 1, we assume that the firm has a demand schedule for invention derived from product market demand. We also assume it faces an upward marginal cost schedule for invention, which represents the cost of generating inventions internally. Without external supply, the equilibrium quantity of inventions is $\mathrm{Q}_{2}$. We further assume, however, that the firm can access external inventions at a constant cost, w. Figure 1 allows us to make two points. First, assuming $\mathbf{w}$ is low enough, it shows that the availability of externally sourced invention can increase the overall rate of invention, in this case from $\mathrm{Q}_{2}$ to $\mathrm{Q}_{3}$, and, in turn, innovation from what it would be in the absence of external supply.. Second, the presence of external sources of invention also yields some substitution of external inventions for internal inventions, represented by $\mathrm{Q}_{2}-\mathrm{Q}_{1}$. Thus, we expect the supply of external technology to affect both the overall rate of innovation and the share of internally generated innovations.

The cost of externally available inventions, w, does not simply reflect the cost of their generation by external parties. There are also numerous costs associated with the acquisition of invention from external sources. The relevant information and rights must be transmissible across firms, and firms often need to expend effort to make the information applicable outside the context in which it was developed (von Hippel, 1990; Arora and Gambardella, 1994). Once transmitted, the knowledge is at risk of misappropriation, and patents in practice offer effective protection in only a small number of industries (Scherer et al., 1959; Levin et al., 1987; Cohen et al., 2000). Williamson (1991) and Teece (1986) also highlight the role of transaction costs in limiting market transactions in knowledge. Mowery (1983) and Kline and Rosenberg (1986) further note the need for ongoing coordination and mutual adjustment across different innovation

\footnotetext{
5 Pisano (1990), in his study of pharmaceutical industry R\&D, is one of many who consider the issue of relying on external invention strictly in terms of "make-or-buy."
} 
stages that can further impede the writing of complete contracts. Finally, it is costly for buyers and sellers of inventions to find one another. Thus, the transfer of inventions across entities is often fraught with difficulties, imposing costs beyond simply the price of the invention (cf. Arora and Gambardella, 2010).

\section{---INSERT FIGURE 1 ABOUT HERE---}

\section{Data: Survey design}

Our data are from a phone survey of firms in U.S. manufacturing and selected service sector industries (see Table A1 in the appendix for a list of the industries in the sample). ${ }^{6}$ In this paper, we focus on the manufacturing sector alone. Our sampling frame was the Dun and Bradstreet (D\&B) Selectory database. Note that we are not sampling on innovators (as done in studies based on patent data), nor on R\&D performers (as done in the Levin et al. (1987) survey and the Carnegie Mellon Survey (Cohen et al., 2000)). ${ }^{7}$

To obtain a substantial number of innovators from each industry, we stratified our sample along multiple dimensions. Because all cases stay in the sample, errors in the D\&B data used for stratification only affect the efficiency of the sampling, not its representativeness (Kalton, 1983). To begin, we selected all the D\&B cases in our population of industries. We took all the Fortune 500 firms in our sample and collected information on all the subsidiaries of those firms that were in our population industries, even if those were not the main industry of the parent firm. These subsidiaries were grouped into business units, defined as a firm's activities within a given NAICS industry, with each subsidiary grouped by its primary NAICS code. For these Fortune 500 firms, the sampling unit is the firm's activity in a NAICS industry (so that a diversified Fortune 500 firm may appear multiple times in the sample). All other firms were assigned a single sampling unit based on their primary NAICS code. The sample was stratified into 28 industries, at the 3- or 4-digit NAICS code level. Finally, the sampling frame was divided by size (Fortune 500, over 1000 employees but not Fortune 500, 500 to 1000 employees, 100 to 499 employees and 10 to 99 employees, and less than 10 employees), and by whether the respondent is a startup, defined as a single-product firm that is less than five years old.

\footnotetext{
${ }^{6}$ NORC, at the University of Chicago, administered our survey.

7 This sampling strategy is analogous to that employed by the Community Innovation Survey (CIS) in Europe and the U.S. National Science Foundation's Business R\&D and Innovation Survey (BRDIS).
} 
We oversampled large firms (Fortune 500, which were sampled with certainty across all business units, and firms of over 1000 employees), startup firms, those from more innovative industries (using Community Innovation Survey (CIS) data from Europe to estimate innovation rates for each industry), those in NAICS code industry 533 (lessors of intellectual property) as a primary or secondary industry and less populated industries (to ensure minimum sample sizes for industry-level estimates). Other categories were under-sampled. We use a post-sample weighting procedure (described below) to make the D\&B data representative of U.S. manufacturing industries.

The survey design included cognitive testing of the questionnaire against potential respondents, pre-testing of the instrument and protocol, and multiple rounds of follow-up contacts to increase response rate. We designed the survey instrument with a branching logic so that non-innovative firms received only a brief questionnaire, and firms that innovated were asked more details about their innovation process and outcomes. The sample consisted of 28,709 cases. An initial screening eliminated many cases, (for example, bakeries that are in retail, not manufacturing) leaving a final sample of 22,034. The interview protocol started with a D\&B contact name (ideally the marketing manager, product manager or, for smaller firms, the business manager), and then worked through the receptionist or other contacts to find an appropriate respondent. ${ }^{8}$

The survey was in the field from May to October, 2010. In the end, we received 6,685 responses, yielding an adjusted 30.3\% response rate. Appendix Table A2 shows the response rates by industry and firm size. Non-response bias tests comparing $\mathrm{D} \& \mathrm{~B}$ data for respondents and non-respondents show that the sample represents the population on firm age, being multiproduct, region, or likelihood to export (how international the firm is). Units of Fortune 500 firms were somewhat less likely to respond (about a 20\% response rate). Similarly, large firms, multi-unit firms and public firms are somewhat less likely to respond. With regard to industry responsiveness, pharmaceuticals had a low response rate, but still over $20 \%$. Further cleaning (based on recoding industries according to survey responses rather than initial D\&B categorizations) identified another 179 out-of-population respondents. For the remaining sample,

\footnotetext{
${ }^{8}$ According to the interview script, an appropriate respondent would be "the marketing manager or another person in your company familiar with the firm's products and services." This flexibility in finding an appropriate contact person was a key rationale for using a phone survey over post-mail or email surveys.
} 
D\&B industry classifications of business units were confirmed, and if necessary updated, based on survey responses. In addition, for the purposes of this paper, we exclude the very smallest establishments (less than 10 employees) and non-manufacturing establishments. The result is a sample of 5157 cases. Appendix Table A3 presents the distribution of our sample, including nonmanufacturing firms, across 48 NAICS code industries (including at least 30 cases in each industry) and firm size classes (collapsed into small [less than 100 employees], medium [1001000 employees] and large [over 1000 employees]).

We reweighted the sample with post-sample weights based on Census data on the population of firms in our industries, size strata and age. We constructed a matrix of these three dimensions of stratification from a custom report provided by the U.S. Bureau of the Census, ${ }^{9}$ and then constructed a set of weights for our 5,157 responses that reflect the population distribution on this three dimensional matrix. After applying these weights, our sample should represent the underlying population in terms of the industry-size-startup distribution (Kalton, 1984). These weights are used in all our empirical analysis.

\section{Findings}

\subsection{Innovation}

In this study, we focus exclusively upon product, rather than process, innovations. Following prior innovation surveys, we asked the respondent if the firm had earned any revenue in 2009 from a new or significantly improved (NOSI) product or service introduced since 2007. For those that said yes, we then asked whether their most significant innovation -- defined as that product innovation accounting for the plurality of 2009 sales in the respondent's market -- was new to the market (NTM), i.e. introduced "in this industry before any other company." 10 We do not specify a geographical boundary to the "industry," and are thus not limiting responses to a local or domestic "market". ${ }^{11}$ Table 1 provides illustrative examples of innovations introduced

\footnotetext{
${ }^{9}$ We thank Ron Jarmin and his team at the U.S. Bureau of the Census for providing this report.

${ }^{10}$ Our NTM figure may underestimate the percentage of firms introducing NTM innovations. For example, a firm's most significant (i.e., highest selling) innovation may not be NTM, but it's second most significant innovation may be, implying that the firm is incorrectly classified as not being an NTM innovator. However, any bias is likely to be small because a sizable fraction of firms introduces only one innovation during the sample period, as discussed below.

${ }^{11}$ We also did not count as innovators firms that reported either that they introduced their "most significant innovation" outside of the 2007-2009 time window, or reported zero 2009 sales revenue due to this innovation.
} 
by firms in the manufacturing sector. We also asked whether our respondents had developed technology for other firms.

About $10 \%$ of our respondents report that they had both supplied technology to another firm and introduced new products to the market. Only $4 \%$ of manufacturing firms had developed technology for another firm but had not themselves introduced a new product to the market. These firms may be considered specialized technology suppliers. In this paper, we focus on firms that commercialize new products.

Table 2 presents summary statistics for the rates of innovation overall and by industry, where we aggregate our observations of firms in the manufacturing sector into 17 industry groups, defined largely at the 3-digit NAICS code level. The figures in Table 2 and all subsequent tables are weighted to be representative of firm size (when reported at the industry level), industry (when reported by firm size) and the true firm size and industry distribution (when reported at the aggregate level).

Table 2 shows that $42 \%$ of firms report introducing a new-to-the-firm (not necessarily new to the market) or significantly improved (NOSI) product in the prior three years. We also find significant differences in the rates of new or improved product introduction across industries. For example, at least $60 \%$ of firms in electronics, pharmaceuticals and semiconductors introduced a NOSI product, while barely one-third of firms in wood or mineral products did so. If we limit product innovations to the introduction of something new to the market (NTM), we find that $16 \%$ of manufacturing firms report having introduced such an innovation, with substantially higher rates in instruments, electronics and pharmaceuticals, while wood and metals have lower rates. Thus, $38 \%$ of firms with a NOSI product report themselves to be the first to bring that product to market, and are classified as innovators. In what follows, the term "innovation" refers to products that are new to the market.

\section{---INSERT TABLE 1 ABOUT HERE---}

Table 2 also shows that larger firms are more likely to innovate and more likely to introduce new products. We find that $39 \%$ of small firms but $65 \%$ of large firms report introducing new products (i.e., new to them). For innovations (i.e., new to the market), the rates were $13 \%$ and $38 \%$ for small and large firms, respectively. Thus, larger firms are more likely to 
have at least one innovation, which is expected in light of the relationship between firm size and R\&D (cf. Cohen and Klepper, 1996). If we interpret the difference between NOSI and NTM as measuring imitation, it follows that innovation increases by firm size but imitation is relatively stable across firm size classes. We observe a similar stability in imitation rates across industries.

\section{---INSERT TABLE 2 ABOUT HERE---}

For those respondents reporting that they innovated (i.e., introduced a NTM innovation), the fourth and fifth columns of Table 2 show the percentage of 2009 sales represented, respectively, by all new-to-the firm products introduced since 2007 and by the single most important product innovation. For all manufacturing firms, we learn that the single most important new product accounts on average for $11 \%$ of the business unit sales while all products that are new to the firm account for $22 \%$ of business unit sales. These figures are sales-weighted. If we take the simple rather than sales-weighted averages, the single most important new or significantly improved product accounts on average for $20 \%$ of the business unit sales compared to $27 \%$ for all products that are new to the firm. The average across firms of the ratio of the percentage sales of the most important new product to that of all new products is $69 \%$, indicating that the revenue impact of new products tends to be highly skewed, which is consistent with Scherer and Harhoff (2000). Indeed, our data further suggests that a sizable share of our sample firms have only one new or significantly improved product over the sample period.

Table 2 also provides the first industry-level estimates of patent propensity for product innovation for all U.S. manufacturing firms. ${ }^{12}$ Fewer than half (42\%) of the innovating firms reported patenting their most significant innovation, with considerable variation across industries and firms. Industries where the share of firms investing in R\&D is higher than average also tend to patent new products at higher than average rates. Nearly two thirds of the large firms patent their most significant innovation compared to only $36 \%$ of small firms. Note that these figures represent patenting by the innovating firm. When the innovation is based on an external invention, we separately ask whether the inventor had a patent on the invention (see below).

\footnotetext{
${ }^{12}$ The Carnegie Mellon Survey reported the patent propensities only for R\&D performing firms, not all innovating firms (Cohen et al., 2000). Nonetheless, and despite the 15 years elapsed between the two surveys, the industry-level patent propensities (i.e., percentage of innovations patented) are similar.
} 
A separate analysis of our data indicates that $94 \%$ of innovating (NTM) firms conduct R\&D and that $89 \%$ of internally-generated innovations are from R\&D (Lee, 2015). For comparison, BRDIS 2011 shows that $94 \%$ of patented inventions came from R\&D performing firms (National Science Board, 2014). On the other hand, 55\% of new-to-firm (NOSI) innovators conduct R\&D, which is to say $45 \%$ of new-to-firm innovators did not report conducting $R \& D$ (Lee, 2015).

To assess the validity of our survey, we compare our findings regarding innovation rates with those from other innovation surveys. The rank order correlation between our survey-based NTM innovation rates at the industry level, and other innovation measures, such as the percentage of firms that conduct R\&D (collected from our survey) or patent, are high, above 0.7. ${ }^{13}$ For the cross-national comparisons, one might expect differences across otherwise comparable national economies simply due to differences in the distribution of respondents across firm size classes and industries and that innovation rates differ across these dimensions. Nonetheless, as compared to $42 \%$ of our respondents that earned revenue in 2009 from (NOSI) products introduced since 2007, the CIS in the UK reports that about $34 \%$ of manufacturing respondents had introduced such a new product between 2006 and 2008. For Germany, 49\% of manufacturing respondents report introducing a new product. Turning to innovation (i.e., NTM), about $38 \%$ of the NOSI respondents in our survey had introduced a product that was new to the market as well. The comparable figure for the UK is $51 \%$ and that for Germany is $45 \%$. Thus, despite differences across the three countries in the rate at which manufacturing firms introduce new products, the share of those products that are new to the market is similar. Moreover, the overall rate of product innovation is also similar to our estimate of $16 \%$, ranging from about $17 \%$ for the UK to $22 \%$ for Germany.

\subsection{Acquisition of inventions by innovating firms}

A key distinction in this paper is between a product innovation (the introduction of a product that is new to the market) and the invention that underlies it. In our survey, we asked our innovating respondents if, for their single most important innovation, an outside source originated the associated invention. The possible sources considered include: 1) a supplier; 2) a

\footnotetext{
${ }^{13}$ Our patent data were obtained from PATSTAT, from which we estimated the percent of firms in each industry that had a patent application.
} 
customer; 3) another firm in the same industry as the respondent; 4) a consultant, commercial lab or engineering service provider; 5) an independent inventor; and 6) a university or government lab. ${ }^{14}$

\section{Sources of invention}

Table 3 shows the different external sources of invention and the rates of reliance on each—overall, by industry, and by firm size. Unlike prior surveys such as the CIS, which ask about the relative importance of external sources of knowledge for a firm's overall innovative activity, we focus on a single innovation (i.e., the most important) and link that particular innovation to the innovation's inputs and outcomes. This method permits estimation of the overall share of innovations that were externally sourced (as distinct from the share of firms that externally sourced at least one innovation), and the relative shares received from different types of sources (customers, suppliers, universities, etc.). We find that $49 \%$ of our respondents reported their most important product innovation originated from an outside source. This figure also changes little across industries distinguished by their R\&D intensities. ${ }^{15}$ The mean number of sources for those respondents that indicate an external source is 1.42 , with $32 \%$ reporting more than one source. Though not reported here, we find that there is no systematic tendency for any one source to be bundled with another, except that, when a respondent indicates a customer to be the source of an invention, the respondent is less likely to identify any other source.

Customers are the single most likely source of external invention, followed by suppliers. The salience of customers as an external source of invention comports with prior literature for both the U.S. and Europe that suggest that customers are an important source of knowledge flows and ideas (e.g., von Hippel, 1986, 2005, Cohen et al., 2002b; Klevorick et al., 1995; Tether, 2002; Veugelers and Cassiman, 1999; Lhuillery and Pfister, 2009). Table 3 also shows

\footnotetext{
${ }^{14}$ The precise wording in our survey of our question about which of these sources may have originated the invention if it came from outside the firm follows: "Did any of the following originate this innovation, that is, create the overall design, develop the prototype or conceptualize the technology?" The firm as a whole may use more sources if it introduces multiple innovations.

${ }^{15}$ Weighting by firm size has relatively little impact on reliance on external sources until we distinguish our industries by R\&D intensity. If we divide our industries on the basis of R\&D intensity (i.e., the $\%$ of respondents that perform R\&D) and weight by overall firm size, we find that, for the most R\&D intensive industries, $66 \%$ of respondents rely on external sources for their most important product innovation, while only about $30 \%$ of respondents in the middle and lowest third of industries, ranked by R\&D intensity, rely upon external sources. In other words, large firms' reliance upon external sources of invention is much more pervasive in more R\&Dintensive industries.
} 
that one of the most notable differences across size classes is that suppliers are a much more likely source of invention for large firms. This makes sense given that it is in suppliers' interests to provide firms with new product ideas that increase input requirements, implying that suppliers likely pay particular attention to the largest firms among their customers.

If we classify consultants, independent inventors and universities all in the same category of "technology specialists," together they account for $17 \%$ of externally sourced inventions. ${ }^{16}$ For respondents reporting specialists as a source, the only noteworthy pattern is that independent inventors are a markedly more common source for small firms. Among our technology specialists, we find that universities are the least frequently used source of inventions, with only $5 \%$ of respondents reporting that they rely upon universities as a source of invention for their most important innovation. ${ }^{17}$ This last result illustrates the importance of distinguishing between sources of knowledge and sources of specific inventions. For example, Cohen et al. (2002b) reported that $29 \%$ of manufacturing firms' R\&D projects used university research results, while only $8 \%$ of R\&D projects made use of prototypes from universities. The former measure is best interpreted as a measure of knowledge flows from universities while the latter is closer to the idea of tangible inventions originating from universities, and is much closer to our finding.

There is substantial variation across industries in the use of different sources. For example, if we use the fraction of firms in an industry that perform R\&D as a measure of an industry's technological intensity, we find that, with a correlation coefficient of 0.40 , industry technology intensity is positively related to innovators' reliance upon universities. In contrast, the correlation coefficients between technological intensity and reliance on customers and suppliers are, respectively, -0.30 and -0.49 , indicating that industries' technology intensity is negatively related to firms' acquisition of inventions from sources in the value chain. These findings are consistent with prior work from the CIS showing differences in the importance of

\footnotetext{
${ }^{16}$ Our aggregation is consistent with Tether and Tajar (2008) and Nieto and Santamaria (2007) who group external collaborations into vertical (suppliers and customers), competitors, and specialists (consultancies, research organizations, and universities). To test the robustness test of our grouping, when we compare the relative value of inventions from different sources in our regression results reported below in Tables $5 \mathrm{a}$ and $5 \mathrm{~b}$, we split the category of technology specialists into its three constituents. We cannot reject the null hypothesis of equality of coefficient estimates in the majority of the specifications.

${ }^{17}$ Once we weight results by overall firm size and divide our industries by R\&D intensity, we see wide disparities in sourcing from universities between the top third of our industries ranked by R\&D intensity versus the bottom third $-13 \%$ vs. $1 \%$ (with the middle third at $6 \%$ ).
} 
information sources between high-tech and low-tech industries (Cox, et al., 2002; Heidenreich, 2009; Köhler, et al., 2012).

The patenting of externally acquired inventions by the innovating firm also varies by source. For example, although $42 \%$ of our innovations are patented, we find only $29 \%$ and $33 \%$ of these innovations are patented when the customer and supplier, respectively, are the sources. This compares to $72 \%, 68 \%$, and $59 \%$ when the invention is sourced from, respectively, a university, an independent inventor, or an R\&D service provider. Thus, where inventions originate from technology specialists generally, the patent rate for the associated innovation is $65 \%$. We consider the implications of the differences in patent rates across sources in section 4.3 below.

\section{---INSERT TABLE 3 ABOUT HERE---}

Our data also indicate the extent to which startups may be a source of inventions for firms that rely on external sources. On average, across all sources, 13\% of those firms relying upon an outside source for their invention report that the source is a startup (defined in our questionnaire as a "new, small company"). Our aggregate figure of $13 \%$ for the contribution of startups to other firms' innovative activities is striking when compared to the incidence of what we define to be startups in our manufacturing sample (i.e., single-product firms that are less than five years old), which is $2.5 \%$. One must be cautious in comparing these numbers since what respondents report to be a startup and our definition of a startup may not correspond. Nonetheless, if one assumes that these numbers are at least roughly comparable, then the large difference between them suggest that startups may play a disproportionately important role in the division of innovative labor.

It has been argued that patents facilitate the transfer of technology (Arora and Ceccagnoli, 2006; Gans et al., 2008). Respondents reported that $24 \%$ of inventions acquired from the outside were patented by the source. Inventions originating from independent inventors were most frequently patented, at a rate of $56 \%$, with universities next at $36 \%$, suppliers at $34 \%$ and R\&D service providers at 28\%. Inventions sourced from technology specialists (i.e., universities, R\&D service providers and independent inventors) are patented at a rate of $37 \%$ 
overall. Inventions sourced from customers are patented by the customers at a rate of $16 \%$. In unreported results, we find that these patterns survive when we control for industry effects and characteristics of the innovator, such as age and size.

\section{Channels}

We asked those firms reporting acquisition of their invention from an outside source about the channel through which they acquired that invention. The channels considered include: 1) merger, acquisition or equity purchase; 2) joint venture or cooperative R\&D; 3) license; 4) a service contract or consulting; or 5) informal means, including informal interaction, reverse engineering or hiring. As with sources, respondents could indicate more than one channel for acquiring the invention from the outside. ${ }^{18}$ The mean number of channels for respondents that used an external channel is 1.44 (with $33 \%$ of those listing a channel giving more than one). As with sources, we found no systematic patterns in the bundling of channels, with one exception: the use of informal channels is associated with lower than average use of other channels.

Table 4 shows that a cooperative effort (i.e., a joint venture or cooperative R\&D) is the single most important channel, accounting for $61 \%$ of externally sourced inventions in manufacturing. ${ }^{19}$ This figure suggests that, in the majority of instances in which a firm acquires an invention from the outside, the firm itself participates in the inventive process. Further, suggesting that cooperative efforts may complement market channels, $27 \%$ of the $61 \%$ of firms reporting an external source also report a cooperative effort along with a market channel, such as a license, an acquisition or a service contract . We also find, however, that $35 \%$ of respondents that report an external source use joint venture or cooperative $R \& D$ as their exclusive channel, with no reported use of a license, service contract or acquisition.

After cooperative efforts, informal channels are the next most frequently cited channel, named by more than a third of the respondents. A service contract or consulting is identified by about a fifth of the respondents as a channel. Licensing is named by $13 \%$ of respondents, and mergers and acquisitions are the least frequently reported channel, though still identified by $10 \%$ of respondents acquiring their invention from an outside source. Table 4 also shows the share of

\footnotetext{
${ }^{18}$ There are 155 respondents who reported an outside source for their invention but did not identify a channel. We treat these 155 observations as missing in our analyses based on channels.

19 Tether (2002), using the CIS2 for the UK, reports that in 1997 , nearly $42 \%$ of innovators in the UK reported cooperation with external partners.
} 
the latter three channels combined into one category, which we call "market channels." The column identified as "Market" indicates that $37 \%$ of the respondents used at least one of these three channels. The "Market only" column indicates that $16 \%$ of respondents report at least one of the three market channels but no non-market channels (i.e., neither a cooperative effort nor an informal channel). In other words, market channels, either alone or employed in tandem with other channels, underpin only a minority share of the division of innovative labor.

Table 4 also shows that large firms favor market channels relative to small firms, while small firms favor informal channels. Medium size firms rely upon joint ventures and cooperative R\&D ventures to a larger extent. We also find that startups as a source were over-represented among those who report using market channels. While, overall, 13\% of the sources were reported to be startup firms, for those innovators who used exclusively market-based channels, $23 \%$ sourced from startups.

There is significant variation in the use of channels across industries. It appears that the more technology intensive sectors favor market channels. Indeed, one of the most R\&D intensive industries in manufacturing, pharmaceuticals, stands quite apart from almost all other industries in its high reliance upon market channels, with $43 \%$ of the respondents reporting use of market channels alone, particularly acquisitions and licensing. More generally, if we use the fraction of firms in an industry that perform R\&D as a measure of an industry's technological intensity, we find that technology intensity is positively related to the use of market channels, with a correlation coefficient of 0.42 . This suggests that the type of channels used may be related to the nature of innovation, such as the extent to which it is science-based, and therefore easier to codify or protect through patents, and, in turn, transfer across firm boundaries (cf. Arora and Ceccagnoli, 2006; Arora and Gambardella, 1994).

\section{---INSERT TABLE 4 ABOUT HERE---}

Among respondents that reported a channel, 27\% of the inventions sourced externally were patented by the source. ${ }^{20}$ Unsurprisingly, inventions sourced via licensing, or a merger and

\footnotetext{
${ }^{20}$ This is slightly higher than the $24 \%$ rate reported above that is obtained when we consider all respondents that use an external invention. Not all firms reporting acquisition of their invention from the outside responded to the question regarding channels, which accounts for the slightly different figure.
} 
acquisition, are most frequently reported to be patented by the source- $58 \%$ for inventions sourced via a merger or acquisition, and $76 \%$ via licensing. Also unsurprisingly, only $3 \%$ of inventions that are sourced exclusively through informal channels are reported to be patented. Inventions sourced exclusively via joint ventures or cooperative R\&D are patented in only $15 \%$ of the cases. These figures suggest that patents facilitate market transactions in technology. They also suggest that patents are not common features of the division of innovative labor when nonmarket channels are employed (with about three-quarters of all externally-sourced inventions not being patented by the source).

Channels are related to sources. For example, technology specialists (i.e., R\&D service providers, universities, and independent inventors) favor market channels. In contrast, ties to suppliers and especially customers are much less likely to involve market channels but rely more on informal and cooperative channels, consistent with the greater trust and familiarity bred of longstanding relationships.

Recall that Table 3 reported $49 \%$ of respondents acquired their inventions from an outside source. This figure includes inventions acquired via informal channels, such as reverse engineering. This may strike some as too comprehensive. If we redefine reliance on outside sources to consist of only acquisition of inventions via formal channels (i.e., license, merger and acquisition, service contract, a cooperative venture), $42 \%$ of innovators rely upon an outside source of invention. Even with this more restrictive definition, we conclude that firms' overall reliance upon outside sources for their most important inventions is extensive.

\subsection{Relative value of inventions by source}

In this section, we combine measures of value and incidence to compare the private cost and value of inventions from different sources. ${ }^{21}$ In terms of the graphical model presented above, we are characterizing how the cost of acquiring external inventions, $\mathbf{w}$, and their private value varies across different sources. We begin by observing that it is not clear what the high incidence of customers as a source of inventions signifies with respect to the relative value of inventions from customers versus other sources, notably technology specialists. For example, it is possible this relatively high incidence suggest that the preponderance of inventions drawn

\footnotetext{
${ }^{21}$ We rely on measures of private commercial value of inventions from various sources, and infer the private costs of obtaining inventions from these sources, as discussed below. Therefore, we can only speak of private rather than social, costs and benefits.
} 
from customers are high value, similar to those originating from the lead users described by von Hippel (1986). Alternatively, it is also plausible that that the cost of acquiring inventions from customers is lower than acquiring them from specialists because repeated interactions with customers result in greater familiarity and trust, leading to lower search and transaction costs. Moreover, if a customer offers an invention to its supplier, it is likely that it believes that the supplier's adoption of that invention will be of benefit to the inventing customer firm.

Accordingly, one might think that such customer-provided inventions may well be offered at cost or even subsidized, consistent with Harhoff et al.'s (2003) finding of pervasive "free-revealing" of inventions by customers. ${ }^{22}$

In contrast, acquiring inventions from specialists will be more costly. First, searching for the right specialist to supply an invention may be costly, as also is putting in place the appropriate contractual and legal safeguards. Second, specialists will only benefit from the invention they provide to a focal firm through the price that they charge for the invention. This point is also consistent with the finding that customer-sourced inventions are patented at less than half the rate of specialist-sourced inventions-16\% versus $37 \%$. It is also consistent with our observation that customer-sourced inventions are less likely to be conveyed through market channels as compared to those inventions originating from technology specialists $-26 \%$ versus $62 \%$.

To address the question of the relative value of customer-sourced versus technology specialist-sourced inventions, we will use our survey data to assess the relative value to the innovator of inventions originating from different sources. To proceed, it is helpful to develop some notation. For the focal innovation, we index the source of invention by $i$, where internal invention is one possible source. The average value of an invention from source $i$ to an innovator is denoted by $\mathrm{V}_{\mathrm{i}}$. The net surplus is given by $\mathrm{V}_{\mathrm{i}}-\mathrm{C}_{\mathrm{i}}$, where $\mathrm{C}_{i}$ represents the cost of acquiring and commercializing invention. The cost of "acquiring" an internally generated invention includes the investment in research required to generate the invention. The cost of acquiring the invention from an outside source also includes any payments made to the source, as well as any

\footnotetext{
${ }^{22}$ Harhoff et al. (2003) documented "free revealing" wherein innovative users freely reveal their invention to firms, who can build upon it to develop a commercial product. Motivated by important examples, including open-source software, the authors argue that a user can derive a variety of benefits from not charging manufacturers for the invention. In Figure 1 above, "free revealing" would shift $\mathbf{w}$ downward, thereby increasing the substitution effect $\left(\mathrm{Q}_{2}-\mathrm{Q}_{1}\right)$ and increasing total innovations $\left(\mathrm{Q}_{3}\right)$
} 
search, contracting and negotiation costs. In addition, all inventions, whether internally generated or externally sourced, have to be developed and brought to the point of market introduction, the costs for which are also included in the relevant cost of acquisition. Value, $\mathrm{V}_{\mathrm{i}}$, corresponds to what we might think of as the present value of revenues earned minus the cost of production.

The extent to which a firm's innovation draws upon a particular source should reflect the net surplus - the value of the invention from that source minus the cost of acquiring and commercializing it. Therefore, Table 3 can be interpreted as saying that inventions sourced from customers provide the highest net surplus compared to suppliers and technology specialists. But is the net surplus from customers so high because the inventions from customers are really valuable or because these inventions are acquired cheaply and easy to commercialize?

Our survey provides a measure of the percentage of a firm's sales in a market generated from their most significant innovation, which can help disentangle cost from value. Sales from innovation have been widely used in the literature (e.g., Laursen and Salter, 2006; Frenz and Ietto-Gillies, 2009) as a measure of the value of the innovation. As long as the sales generate similar net margins over cost across firms in an industry, and as long as sales do not cannibalize sales of existing products, a higher share of sales will imply a higher profitability associated with the product. Column 1 of Table 5a presents results from regressing (OLS) the logarithm of the percentage of sales revenue due to the focal innovation against sources of inventions. The specification includes controls for age, size (log of employment), whether the respondent conducts R\&D, as well as 45 industry dummies at the 3-digit NAICS-code-level of industry aggregation. Internal invention is the reference source.

Assuming percentage of sales is a reasonable indicator of value, the first column in Table 5a suggests that, whereas inventions sourced from customers are less valuable than internal inventions, those from specialists are more valuable. Note that these results are conditional upon a source being chosen and thus may be subject to selection bias. Specifically, if the cost of inventions from customers is less than that sourced from specialists, the marginal invention actually sourced from a customer will also be lower in value than those from specialists. Consequently, the observed mean value of inventions sourced from customers will also be lower than those sourced from specialists even if the customer and specialist-generated inventions have the same distribution of value.

This is illustrated in Figure 2, which depicts a hypothetical distribution of value for 
different sources. Focusing on the value distribution for innovations sourced from customers (the solid line graph), we see that the observed mean of value is equal to the mean conditional upon the value, $\mathrm{V}$, being greater than the cost, $\mathrm{C}$. It is easy to see that as the cost, $\mathrm{C}$, increases, the observed mean will also increase but the probability of observing an innovation from that source will fall. The challenge for us is to evaluate whether the value distribution of inventions from specialists, customers and other sources differ from each other, while allowing for the costs of acquisition to also differ.

\section{---INSERT FIGURE 2 ABOUT HERE---}

We take two complementary approaches. A simple test of the null hypothesis that the value distributions are the same and only the cost of acquisition differs between customers and specialists is to focus on the right tail of the distribution. In Figure 2, if both customers and specialists have the distribution marked by the solid curve then the area under the curve to the right of the point $t$ should be the same for both customers and specialists. That is to say, the probability of value being larger than $t$ conditional upon the source being a customer should be the same as that of a specialist. This is represented by the shaded triangle abt in Figure 2. Intuitively, the right tail of the conditional distribution should be unaffected by the truncation due to the differing costs, and thus, if the two distributions are the same, the right tail should be the same as well.

More precisely, $\mathrm{G}(\cdot)$ and $\mathrm{H}(\cdot)$ represent the cumulative distributions of the value of customer inventions $\left(\mathrm{V}_{\mathrm{c}}\right)$ and specialists $\left(\mathrm{V}_{\mathrm{s}}\right)$ respectively. Let the cost of acquisition from customers versus specialists be $C_{c}$ and $C_{s}$, respectively, where we expect $C_{s}>C_{c}$. Thus the probability of customers being a source is $1-\mathrm{G}\left(\mathrm{C}_{\mathrm{c}}\right)$ and of specialists being a source is $1-\mathrm{H}\left(\mathrm{C}_{\mathrm{s}}\right)$. Consider a point $t_{1}>C_{s} \geq C_{c}$. The probability that the observed value from a customer invention is less than $t_{1}$ is therefore $G\left(t_{1}\right) /\left(1-G\left(C_{c}\right)\right)$. Similarly, the probability that the observed value of a specialist invention is less than $\mathrm{t}_{1}$ is $\mathrm{H}\left(\mathrm{t}_{1}\right) /\left(1-\mathrm{H}\left(\mathrm{C}_{\mathrm{s}}\right)\right)$. Under the null hypothesis that $\mathrm{G}(\cdot)$ is the same as $\mathrm{H}(\cdot)$, the ratio of the two probabilities is $\left(1-\mathrm{H}\left(\mathrm{C}_{\mathrm{s}}\right)\right) /\left(1-\mathrm{H}\left(\mathrm{C}_{\mathrm{c}}\right)\right)$, which is independent of $\mathrm{t}_{1}$, implying that the ratio of the observed value distributions for inventions from customers and specialists should be constant. The data suggest that the ratio in fact is higher for low value innovations and much smaller for high value innovations. Figure 3 shows the frequency 
distribution of the share of sales from the focal innovation obtained from customers (light shaded bars) and specialists (dark bars) ${ }^{23}$ We see that $16 \%$ of specialist inventions but fewer than $5 \%$ of customer inventions are in the top category (accounting for 50\% or more of total sales), a probability ratio of over 3.5. The probability ratio is only 1.45 for the next category of innovations (accounting for between $25 \%$ and $50 \%$ of sales revenue), with $22 \%$ of specialist inventions and $15 \%$ of customer invention in this category. Similarly, only $19 \%$ of specialist inventions and over $25 \%$ of customer inventions fall in the next category of innovations (accounting for 11 to $25 \%$ of sales), implying a probability ratio of only 0.74 . This makes it highly unlikely that the difference between customers and specialists in the conditional means of the share of sales from the focal innovation is due entirely to differences in the costs of acquisition. ${ }^{24}$ Instead, the data suggest that specialist-sourced inventions are more valuable, on average.

Figure 3 of course does not control for firm characteristics or industry. Table 5a presents results that include such controls. Column 2 in Table 5a shows the result of a linear probability model where the dependent variable is 1 if the percent of sales from the focal innovation is greater than $50 \%$ (which corresponds to $9 \%$ of the sample of all innovations). ${ }^{25}$ Even after controlling for business unit size, parent firm size, firm age, whether the respondent conducts R\&D or not, and industry fixed effects, we see that $17 \%$ of inventions from specialists are high value (account for over $50 \%$ of sales) whereas only $2 \%$ of inventions from customers are high value. Neither this regression analysis, nor the results in column 1, control, however, for selection.

\section{---INSERT FIGURE 3 ABOUT HERE---}

\footnotetext{
${ }^{23}$ Firms indicating multiple sources were divided proportionately. Thus, a respondent that indicated both a supplier and a customer is allocated 50-50 to each source.

${ }^{24}$ More formally, if we let $\lambda=\left(1-\mathrm{H}\left(\mathrm{C}_{\mathrm{s}}\right)\right) /\left(1-\mathrm{G}\left(\mathrm{C}_{\mathrm{c}}\right)\right)$, we can write the difference in the observed probability of inventions following in category $\mathrm{t}_{\mathrm{i}}$ as $\lambda \mathrm{h}\left(\mathrm{t}_{\mathrm{i}}\right)-\mathrm{g}\left(\mathrm{t}_{\mathrm{i}}\right)$. Under the null hypothesis that the two distributions are the same, $1 \geq \lambda \geq 0$, and $\sum_{i}\left(g^{*}\left(t_{i}\right)-h^{*}\left(t_{i}\right) \lambda\right)^{2}$ can be used to form the Kolmogorov Smirnov test statistic for a given $\lambda$.

Therefore, we performed a grid search over $\lambda$ to find the lowest value of $\sum_{i}\left(g^{*}\left(t_{i}\right)-h^{*}\left(t_{i}\right) \lambda\right)^{2}$, which then forms the test statistic. We are able to reject the null hypothesis at the $1 \%$ level of significance.

${ }^{25}$ Using a linear probability specification rather than a probit or logit is preferred because it is robust to misspecification and more conservative.
} 
A different approach to the selection problem from our graphical analysis in Figure 3 incorporates the possibility that a given firm can potentially choose from among different sources. Therefore, the observed innovation must not only cover the cost of acquiring it, but the net surplus from obtaining it must exceed the net surplus from alternatives. As explained in Appendix B, we follow Dubin and McFadden (1984) and use a multinomial logit framework to express the mean value of an invention conditional upon a specific source of the invention as the unconditional mean value of inventions from that source plus the natural logarithm of the share of the source in the industry. The latter is analogous to the familiar Heckman selection term. We then assume that the mean value of invention from the source $i$ in industry $k$ for innovator $j$ is a linear function of a vector of firm characteristics, $X_{i}$, an industry fixed effect, $z_{k}$ and a source fixed effect, $\mathrm{s}_{\mathrm{j}}$. This leads to the specifications in columns 3 and 4 of Table $5 \mathrm{a}$.

\section{---INSERT TABLE 5A ABOUT HERE---}

Comparing columns 1 with 3 , and 2 with 4 in Table 5a shows that this correction for selection leaves the basic pattern of results unchanged. The correction term, the log of the share of the source, is imprecisely estimated. We obtain similar results (not reported here) when we use a second order polynomial in the predicted probability instead of its natural log to control for sample selection, although the coefficient on the correction term is again not significantly different from zero. ${ }^{26}$ In sum, our results indicate that customer sourced inventions are cheaper to acquire and are lower in their commercial value.

\section{---INSERT TABLE 5B ABOUT HERE---}

To probe the robustness of our results, Table $5 \mathrm{~b}$ reports the results using other indicators of value to compare the value offered from different sources. Each of the indicators is imperfect but they all point in the same direction, and it is the robustness of the patterns below to which we appeal. For example, another possible indicator of value is investment associated with the

\footnotetext{
${ }^{26}$ Dahl (2002) uses a polynomial of this share as a "correction" function to correct for the selection bias. Dahl's approach does not require a multinomial framework. In a multinomial framework, the natural log of the predicted probability is the appropriate correction, as shown by Dubin and McFadden (1984).
} 
commercialization of the invention. We asked innovating firms whether, to commercialize the innovation, they developed new sales and distribution channels, and separately, whether they had invested in new types of equipment or hired employees with distinct skills. A firm will undertake these actions only if it expects a return - that is, the new product in question is valuable enough to justify the investment. In Column 1 of Table 5b, we see that innovations sourced from specialists are associated with a greater likelihood of investment in new plant and equipment or in hiring personnel with different expertise. By contrast, the coefficients on inventions from other sources are not statistically different from zero. The results in Column 2 similarly show that inventions sourced from specialists are associated with the innovating firm investing in new sales and distribution channels, while other sources do not have significant estimated coefficients. $^{27}$

We use two other indicators of value. The first is whether the innovator (as distinct from the source) filed for a patent for some aspect of the innovation. ${ }^{28}$ Column 3 of Table $5 \mathrm{~b}$ shows that the innovator is significantly more likely to patent inventions sourced from specialists as compared to internally generated inventions. Conversely, innovations sourced from customers or suppliers are significantly less likely to be patented. Recall that these regressions included industry fixed effects, and thus control for cross-industry differences in patent propensities.

Our final indicator considers the outcome for the firm as a whole, instead of focusing only on the focal innovation. We asked all firms whether their market share had increased, decreased or stayed the same over the sample period. Just over $60 \%$ of the innovating firms report an increase in market share. In Column 4, we see that, relative to internally innovating firms, customer-sourced innovations are associated with a higher probability of a decline in the firm's market share. In contrast, specialist-sourced innovations are associated with an increase in the firm's overall market share (relative to internally generated inventions), as we would expect from more valuable innovations. Inventions from suppliers and other firms appear to be similar to internal invention in value.

\footnotetext{
${ }^{27}$ Absence of investment in sales and distribution channels may be expected in the case of customers simply because the focal firm was already selling to the customer that was the source of the invention. This logic does not, however, apply to investment in plant and new types of personnel, as considered in column 1.

${ }^{28}$ Patents are an imperfect measure of value. An innovation may not be patentable or there may be strategic reasons not to patent.
} 
Thus, across a wide variety of indicators of value, including measures of both investments and outcomes, a consistent story emerges from the results presented in Tables 5a and 5b: the average (unconditional) value of inventions sourced from customers are lower than those sourced from technology specialists. ${ }^{29}$ While each of these indicators has shortcomings, the consistency of this finding is compelling. Recall, however, that Table 3 shows that, after internal invention, the relative incidence of customers as a source of invention is the highest, followed by technical specialists, suppliers, and other firms - and this relative incidence indicates that, on average, the net surplus (i.e., V - C), among external sources, is highest for customers. These two conclusions can be reconciled in only one way: while the highest gross value is realized from technology specialists, with customer-sourced inventions having the lowest, the cost of acquiring inventions from customers is low enough to make the net surplus - and hence, the incidence — of customer-sourced inventions rank highest among all externally sourced inventions. In other words, the high incidence of inventions sourced from customers reflects the low cost of acquiring and commercializing such inventions, rather than high value.

Our results suggesting that customers offer relatively low value inventions contrast with what we might expect if we think that the typical customers providing inventions to firms are the lead users described by von Hippel $(1986,2005)$. Though our results are entirely consistent with a fraction of customers providing high-value inventions, they also suggest that, on average, customer-sourced inventions will be of lower commercial value relative to those of specialists. ${ }^{30}$ And this is not surprising. First, customers may tend to anchor their suggestions on existing products. Second, insofar as customers are other firms, Christensen's (1997) work would suggest that industrial customers tend to push for more incremental invention to avoid the costs of the changing of equipment, personnel or even organizational structure that more significant innovation on the part of the supplier may entail. And it is indeed the case that industrial customers are more likely to be sources of invention than final consumers: in industries that the U.S. BEA identifies as intermediate capital goods industries, $30 \%$ of our sample innovating firms

\footnotetext{
${ }^{29}$ Consistent with our findings, Sofka and Grimpe (2009) report, for a sample of 5000 Western European firms, the share of revenue from innovative products is higher for firms that stress collaboration with universities and research centers, and for firms that stress collaboration with suppliers.

${ }^{30}$ Given our focus on private value, this is consistent with Riggs and von Hippel's (1994) findings in the case of scientific instruments that the commercial value of user-originated inventions are less than that of manufactureroriginated innovations, even while the scientific or social value of the former may be greater.
} 
list customers as a source for their inventions, versus $18 \%$ of the innovating firms in industries identified as final goods industries. ${ }^{31}$ In contrast to customers, technology specialists should have no systematic interest in promoting incremental invention but rather a strong interest in promoting more significant, valuable innovations if they are to compete against the firm's own $R \& D$ operations and other sources of invention.

Our analysis not only implies that inventions from customers will be of lower average value, but also that the cost of their acquisition and commercialization will be lower still. This inference is consistent with our argument that customer-sourced inventions will tend to be more incremental, and thus easier to implement and commercialize, and require less development effort. Further, customer-sourced inventions will often require less investment in sales and marketing because the customer that originated the invention is likely to be among the early buyers. Finally, as noted above, cost will be lower because it is often in the customer's interest to charge the upstream firm little - per Harhoff et al.'s (2003) observation of free-revealing - since the customer benefits from the upstream firm's commercialization of the underlying invention.

\subsection{External supply and the rate of innovation}

Given that sources differ in their costs and benefits, what can we infer about their possible contributions to the overall rate of innovation? To address this question, we first employ a multinomial logit framework to examine the relationship between source selection and the overall rate of innovation. We will follow this analysis with a complementary approach to the question that draws more directly from our survey data.

Subordinating the details of the derivation to Appendix B, if $\mathrm{P}_{i}$ is the probability of obtaining invention from source $i$, and $\mathrm{P}_{0}$ is the probability of no innovation, the contribution of source $i$ to the overall rate of innovation in the economy - the percentage reduction in innovation rates if that source of invention became unavailable-is:

$$
\left[\mathrm{P}_{0} /\left(1-\mathrm{P}_{0}\right)\right]\left[\left(\mathrm{P}_{\mathrm{i}}\right) /\left(1-\mathrm{P}_{\mathrm{i}}\right)\right] .
$$

We can calculate the contribution of various external sources to innovation by applying (1) to data grouped at the industry level. We use the share of inventions from source $i$ to compute $\mathrm{P}_{i}$. We use the 17 industry groups used in Table 2, and take a sales-weighted average over the

\footnotetext{
${ }^{31}$ Consistent with these findings, Adams et al. (2013) highlight the important contribution of industrial users to innovation in the semiconductor industry.
} 
industries to obtain the contribution of each source. We report bootstrap standard errors based on 500 draws. The results are summarized in Table 6.

Table 6 reports the contribution to the innovation rate for the manufacturing sector as a whole by each source, and by external sources overall. From Table 2, we see that $16 \%$ of the firms innovate, and in Table 3 we show that about $49 \%$ of these innovators rely upon external sources of invention. Equation (1) implies that removing all external sources of invention would reduce overall innovation by $45 \%$ (Table 6). Put differently, if external sources of innovation were not available, only about $9 \%$ of the firms would innovate instead of $16 \%$. Such a hypothetical corporate self-sufficiency in innovation would cost the U.S. manufacturing dearly. Consistent with Table 3 above, customers make the greatest contribution of all external sources, followed by specialists, suppliers, and other firms. ${ }^{32}$

\section{---INSERT TABLE 6 ABOUT HERE---}

These calculations are subject to the strong assumptions of the multinomial logit framework. For one, these inferences depend upon the pattern of substitutions across sources. ${ }^{33}$ Substitution between sources means that the drop in innovation from losing a given source $i$ is less than $\mathrm{P}_{i}$. However, because some of the substitution would result in the firm choosing not to innovate, the overall rate of innovation will decline. Specifically, since over $80 \%$ of manufacturing respondents do not innovate, this implies, in a multinomial logit framework, that "no innovation" is the most likely counterfactual outcome if a source were removed.

Such counterfactuals are difficult to test. We have, however, another basis for projecting what may happen in the absence of external sources of invention. For externally sourced innovations, we asked respondents whether the firm could have acquired the invention from another source. Only one third (33\%) of the respondents indicated that they could. Even if one conservatively assumes that the alternative source is always internal invention, then the removal of all external sources would imply that, at best, only a third of the $8 \%$ of respondents who sourced their inventions externally, or fewer than 3\%, would still innovate. If so, the rate of

\footnotetext{
${ }^{32}$ In a multinomial logit setup, the contribution of any source is proportional to its share of innovations.

${ }^{33}$ In particular, the multinomial logit setup implies that if customers were removed as a possible source, innovators using customer-sourced inventions would use the other sources in proportion to the shares of the sources, so that the relative shares of the remaining sources would remain unchanged.
} 
innovation would fall from $16 \%$ to about $11 \%$ or less. Based on this survey item, if external sources of inventions were unavailable, the overall rate of innovation would fall by at least $30 \%$ (more if the 33\% included alternative external sources). Thus, both of these estimates, based on very different indicators and analyses, suggest a substantial reduction in innovation if external sources of invention were not available.

Though subject to a variety of qualifications, the point of this section is to highlight that the extent to which innovations rely upon external sources of invention and the overall rate of innovation are jointly determined. As Figure 1 showed, external sources of invention may not simply substitute for internal invention; they can also condition the overall rate of innovation. Thus, removing a particular source should have two effects - a less efficient source would be selected in some cases, and in others, the firm may not innovate at all.

\section{Conclusion and implications for policy and management}

Based on a survey of U.S. manufacturing firms, we find that almost half of innovating firms had an external source for the invention that led to their most important (new to the market) innovation. The most common external source was customers, accounting for about one quarter of all innovations, with technology specialists (i.e., universities, consulting/contract engineering firms, independent inventors) the second most common external source, accounting for almost one fifth of all innovations. In addition, among these invention sources, startups appear to be over-represented. Furthermore, we find that only a minority of these inventions was acquired through market channels (i.e., licensing, mergers \& acquisitions, and service contracts). However, when a market-based channel was employed, the source was disproportionately likely to have had a patent on the invention and was also disproportionately likely to be a startup.

Our analysis extends beyond the reporting of the findings of our survey by offering an understanding of not only the incidence but also the relative cost and value of inventions supplied by different sources. Using information on the share of sales accounted for by our respondents' most significant product innovations supplemented by data on respondents' subsequent investments in commercialization of their innovations, patenting and market share data, we show that inventions sourced from technology specialists tend to be privately the most valuable, and those sourced from customers tend to provide the highest net surplus to innovators because they are the least costly to acquire. 
External sources are not, however, simply substitutes for internal inventions; they also lead some firms to innovate that otherwise would not, thus augmenting the percentage of firms that innovate. In other words, external sourcing of invention is not simply a matter of "make-orbuy." If firms did not have access to external sources, our data suggest that the overall rate of innovation of $16 \%$ would likely drop to about $10 \%$ (9\% to $11 \%$ depending on the indicator). While this estimate should be interpreted with caution given the strong assumptions underlying our analyses, the main point is that external sources do not simply substitute for internally generated innovation, but also contribute to the overall rate of innovation, perhaps substantially.

There are several important limitations of our analysis. First, we cannot causally link the value of innovation to the sources of invention. We have, however, amassed a variety of direct and indirect evidence that some sources offer higher value inventions than others. Similarly, our estimate of the relation between external sourcing and the innovation rate depends on strong assumptions related to the multinomial logit model. However, the consistency of the estimate based on respondent's self-reported estimates of the availability of alternative sources of invention gives us more confidence in this result.

Aside from the substance of what we have learned, our approach to the design of our survey also offers methodological benefits. By focusing on a single innovation, we are able to link the particular innovation directly to several indicators of its value. This allows us to address the ambiguity surrounding the notion of an innovation or what might be a new or significantly improved product that has been a concern for surveys based on the current Oslo Manual (cf. Arundel, 2006; Tether, 2001; Smith, 2005). Our data also focus on the sources of inventions tied to specific innovations, rather than the broader category of knowledge sources (cf. Cohen, et al., 2002b; Frenz and Ietto-Gillies, 2009), permitting us to characterize the division of innovative labor between inventors and innovators. Also, by asking about a single innovation, we can develop estimates of the share of innovations that are externally acquired, and the prevalence of each type of source, thus providing precise estimates of the extent of the division of innovative labor between inventors and innovators. Furthermore, this method allows linking those sources to specific measures of value, and to estimates of their contribution to the overall rates of innovation.

Our findings raise two questions pertaining to social welfare. First, is the current state of external sourcing socially optimal? Second, is the current balance between market and non- 
market channels for acquiring inventions — where non-market channels currently predominatesocially desirable? Our findings allow us to claim neither that the current state of external sourcing of invention in U.S. manufacturing is socially suboptimal, nor whether more marketbased acquisition is indicated. We conjecture, however, that the efficiency of sourcing, and especially market-based sourcing, can be enhanced. There are a variety of policies and practices that would make external sourcing more efficient (i.e., lowering w in Figure 1). For example, more certainty in patent protection would likely increase licensing of inventions (Gans et al., 2008), as would greater transparency of the terms of deals in technology markets. The supply of high value university inventions would also likely increase if universities were to adopt standard licensing forms and other practices that diminish transaction costs (cf. National Research Council, 2010, p. 88).

Changes in private policies and practices could also increase the efficiency of the division of innovative labor. There are organizational barriers to the external sourcing of inventions. Changing the "not-invented-here" culture, for example, that still pervades some large firms could well offer social as well as private benefits. Indeed, our results reinforce the need to consider ways in which managers may improve the efficiency of acquiring inventions from external sources. The importance of listening to customers has been touted in the popular writing on the subject, and user-innovation is by now broadly accepted by innovation scholars. Our findings suggest that managers should also attend to high-value sources such as universities and independent inventors. That independent inventors appear to disproportionately favor small firms as compared to larger ones may signal that large firms may be missing an opportunity. ${ }^{34}$

Our findings also offer an important implication for empirical scholars studying the determinants of R\&D spending and technological change. Firms' pervasive reliance on outside sources for their inventions implies that innovation rates across industries depend upon factors that condition the supply of invention from sources outside the firm and often outside the industry. In their efforts to explain the innovation rates of firms and industries, empirical scholars would be well advised to consider these factors along with those that are typically considered

\footnotetext{
${ }^{34}$ A different interpretation is that small firms act as a bridge between independent inventors and larger firms, who may find it too costly to deal with independent inventors. Indeed, in biopharmaceuticals, biotech firms function as a bridge between university-based inventors and large pharmaceutical firms (Edwards, et al., 2006).
} 
either at the industry level, such as demand, technological opportunity and appropriability conditions, or at the firm level, such as firm capabilities or cash flow (cf. Cohen, 2010).

Our findings also have implications for recent debates about patent reform. Recent debates about "patent-assertion entities" (PAE's), sometimes called "patent trolls," have led to calls for reforming the patent system to limit the ability of such entities to sue for patent infringement. The strong link we find between patents and market-based acquisitions of inventions suggest that patents may play an important role in facilitating market transactions for technology. We find that a quarter of the inventions obtained from external sources were patented by the inventor, implying that the overwhelming majority of the inventions transferred do not rely upon patents. High value inventions from universities, independent inventors, and R\&D contractors are, however, much more likely to be patented than those from the other sources. Thus, our results suggest that in crafting patent reform legislation addressing the abuses of PAE's, one must take care to not undermine technology specialists (e.g., independent inventors, universities) who appear to rely heavily on patent protection and are the most valuable source of inventions.

In conclusion, our results suggest that the division of innovative labor is prevalent, and involves multiple types of actors and a variety of institutional arrangements linking them. Policy, both public and private, must consider innovation as the product of a system rather than simply focus on the individual elements such as startups or large corporations. 


\section{References:}

Adams, P., Fontana, R., and Malerba, F. (2013). The magnitude of innovation by demand in a sectoral system: The role of industrial users in semiconductors. Research Policy. 42, pp. $1-14$.

Arora, A. \& Ceccagnoli, M. (2006). Patent protection, complementary assets, and firms' incentives for technology licensing." Management Science 52(2): 293-308.

Arora, A., \& Gambardella, A. (2010). The market for technology, in Handbook of the Economics of Innovation, Bronwyn H. Hall, and Nathan Rosenberg (eds.), 2010, North-Holland, Elsevier Press, Amsterdam and Oxford

Arora, A., \& Gambardella, A. (1994). The changing technology of technological change: general and abstract knowledge and the division of innovative labour. Research Policy, 23(5), 523-532.

Arora, A., and Gambardella, A. (1990). Complementarities And External Linkages: The strategies of large corporations in biotechnology, Journal of Industrial Economics, 38(4): 361-379.

Arora, A., Fosfuri, A., \& Gambardella, A. (2001). Markets for Technology: The Economics of Innovation and Corporate Strategy, MIT Press, Boston MA.

Arundel, A. (2006). Innovation survey indicators: Any progress since 1996?, UNU-Merit working paper.

Belderbos, R., Carree, M. and Lokshin, B. (2004). Cooperative R\&D and firm performance. Research Policy 33.10: 1477-1492.

Chesbrough, H. W. (2003). Open innovation: The new imperative for creating and profiting from technology. Harvard Business Press.

Christensen, C. (1997). The innovator's dilemma: when new technologies cause great firms to fail. Harvard Business Press.

Cohen, W. M. (2010). Fifty years of empirical studies of innovative activity and performance. Handbook of the Economics of Innovation, 1, 129-213.

Cohen, W. M. (1995). Empirical Studies of Innovative Activity, in Stoneman, P. (ed.), Handbook of the Economics of Innovation and Technological Change, Basil Blackwell, Oxford.

Cohen, W. M., Goto, A., Nagata, A., Nelson, R. R., \& Walsh, J. P. (2002a). R\&D spillovers, patents and the incentives to innovate in Japan and the United States. Research Policy, 31(8), 1349-1367.

Cohen, W. M., \& Klepper, S. (1996). A reprise of size and R \& D. The Economic Journal, 925951.

Cohen, W. M., Nelson, R. R., \& Walsh, J. P. (2000). Protecting their intellectual assets: Appropriability conditions and why US manufacturing firms patent (or not) (No. w7552). National Bureau of Economic Research.

Cohen, W. M., Nelson, R. R., \& Walsh, J. P. (2002b). Links and impacts: the influence of public research on industrial R\&D. Management Science, 48(1), 1-23.

Cox, H., Frenz, M., Prevezer, M., 2002. Patterns of Innovation in UK Industry: Exploring the CIS Data to Contrast High and Low Technology Industries. Journal of Interdisciplinary Economics 13, 267-304.

Dahl, G. B. (2002). Mobility and the returns to education: testing a Roy Model with multiple markets. Econometrica 70: 2367-2420. 
Dubin, J., and D. McFadden (1984). An Econometric Analysis of Residential Electric Appliance Holdings and Consumption, Econometrica, 52, 345-362.

Dubin, J. (1985). Consumer Durable Choice and the Demand for Electricity. New YorkAmsterdam: North-Holland Publishing Company, 1985

Edwards, M., Murray, F. \& Yu, R. (2006). Gold in the ivory tower: equity rewards of outlicensing. Nature Biotechnology 24(5): 509-515.

Frenz, M., Ietto-Gillies, G. (2009). The impact on innovation performance of different sources of knowledge: Evidence from the UK Community Innovation Survey. Research Policy 38, 1125-1135.

Freeman, C. (1991). Networks of innovators: a synthesis of research issues. Research Policy, 20(5), 499-514.

Gans, J. S., Hsu, D.H. \& Stern, S. (2008). The impact of uncertainty intellectual property rights on the market for ideas: evidence from patent grant delays. Management Science 54(5): 982-997.

Griliches, Z. (1992). The Search for R\&D Spillovers. The Scandinavian Journal of Economics. S29-S47.

Hagedoorn, J. (2003). Sharing intellectual property rights: an exploratory study of joint patenting amongst companies. Industrial and Corporate Change. 12 (5): 1035-1050.

Harhoff, D., Henkel, J., von Hippel, E. (2003). Profiting from voluntary information spillovers: how users benefit by freely revealing their innovations. Research Policy 32, pp. 17531769.

Heidenreich, M., 2009. Innovation patterns and location of European low- and mediumtechnology industries. Research Policy 38, 483-494.

Henderson, R., Jaffe, A., Trajtenberg, M. (1998). Universities as a Source of Commercial Technology: A Detailed Analysis of University Patenting, 1965-1988. Review of Economics and Statistics. February Vol. 80, No. 1, Pages 119-127.

Jewkes, J., Sawers, D., \& Stillerman, R. (1969). The Sources of Invention (Vol. 214, p. 215). London: Macmillan.

Kalton, G. (Ed.) (1983). Introduction to survey sampling (Vol. 7, No. 35). SAGE Publications, Incorporated.

Kalton, N. J. (1984). An F-space sampler (Vol. 89). CUP Archive.

Klevorick, A. K., Levin, R. C., Nelson, R. R., \& Winter, S. G. (1995). On the sources and significance of interindustry differences in technological opportunities. Research Policy, 24(2), 185-205.

Kline, S. J., \& Rosenberg, N. (1986). An overview of innovation. in R. Landau and N. Rosenberg, Eds. The Positive Sum Strategy: Harnessing technology for economic growth, 14, 640.

Köhler, C., Sofka, W., Grimpe, C., 2012. Selective search, sectoral patterns, and the impact on product innovation performance. Research Policy 41, 1344-1356.

Lee, Y. (2015). Evaluating and extending innovation indicators for innovation policy. Research Evaluation 4(4), 471-488.

Laursen, K., and Salter. A. (2004). Searching high and low: what types of firms use universities as a source of innovation? Research Policy. 33(8), 1201-1215

Laursen, K., and Salter. A. (2006). Open for innovation: the role of openness in explaining innovation performance among U.K. manufacturing firms. Strategic Management Journal. 27(2): 131-150. 
Laursen, K., \& Salter, A. J. (2014). The paradox of openness: Appropriability, external search and collaboration. Research Policy, 43(5), 867-878.

Levin, R. C., Klevorick, A. K., Nelson, R. R., Winter, S. G., (1987). Appropriating the returns from industrial research and development. Brookings Papers on Economic Activity, 1987(3), 783-831.

Lhuillery, S., \& Pfister, E. (2009). R\&D cooperation and failures in innovation projects: Empirical evidence from French CIS data. Research Policy, 38(1), 45-57.

Mohnen, P. and Röller, R.(2005). Complementarities in innovation policy., European Economic Review. Volume 49, Issue 6, August 2005, Pages 1431-1450

Mowery, D. C. (1983). The relationship between intrafirm and contractual forms of industrial research in American manufacturing, 1900-1940. Explorations in Economic History, 20(4), 351-374.

Mueller, W.F. (1962). The origins of the basic inventions underlying DuPont's major product and process innovations, 1920 to 1950. In: Nelson, R.R. (Ed.), The Rate and Direction of Inventive Activity. Princeton University Press, Princeton, NJ.

National Research Council (2010). Managing University Intellectual Property in the Public Interest, Washington: National Academies Press.

National Science Board (2014). Science and Engineering Indicators 2014. Arlington VA: National Science Foundation (NSB 14-01).

Nieto, M. J., \& Santamaría, L. (2007). The importance of diverse collaborative networks for the novelty of product innovation. Technovation, 27(6), 367-377.

Pavitt, K. (1984). Sectoral patterns of technical change: towards a taxonomy and a theory. Research Policy 13 (6), 343-373.

Pisano, G. (1990) The R\&D Boundaries of the Firm, Administrative Science Quarterly 35:1, pp. 153-176.

Poot, T., Faems, D., \& Vanhaverbeke, W. (2009). Toward a dynamic perspective on open innovation: A longitudinal assessment of the adoption of internal and external innovation strategies in the Netherlands. International Journal of Innovation Management, 13(02), 177-200.

Riggs, W., \& Von Hippel, E. (1994). Incentives to innovate and the sources of innovation: the case of scientific instruments. Research Policy, 23(4), 459-469.

Scherer, M., and Harhoff, D. (2000). Technology policy for a world of skew-distributed outcomes. Research Policy 29, 559-566.

Scherer, F.M., Herzstein, S., Jr., Dreyfoos, A., Whitney, W., Bachmann, O., Pesek, C., Scott, C., Kelly, T., Galvin, J. (1959). Patents and the Corporation (second ed.). Privately published, Boston, MA.

Schumpeter, J.A. (1939). Business Cycles: A Theoretical, Historical, and Statistical Analysis of the Capitalist Process. Abridged. New York: McGraw Hill.

Smith, K. (2005). Measuring innovation. in J. Fagerberg, D.C. Mowery and R.R. Nelson, The Oxford Handbook of Innovation, Oxford: Oxford University Press.

Sofka, W. and Grimpe, C. (2010). Specialized search and innovation performance-evidence across Europe. R\&D Management, 40(3), 310-323.

Teece, D. J. (1986). Transactions cost economics and the multinational enterprise An Assessment. Journal of Economic Behavior \& Organization, 7(1), 21-45. 
Tether, B. (2001). Identifying innovation, innovators and innovative behavior: A critical assessment of the Community Innovation Survey, University of Manchester, CRIC Discussion Paper No. 48.

Tether B. (2002). Who co-operates for innovation, and why: An empirical analysis. Research Policy. Volume 31, Issue 6, August 2002, pp. 947-967.

Tether, B. S., \& Tajar, A. (2008). Beyond industry-university links: Sourcing knowledge for innovation from consultants, private research organisations and the public science-base. Research Policy, 37(6), 1079-1095.

Veugelers. R. \& Cassiman, B. (1999). Make and buy in innovation strategies: evidence from Belgian manufacturing firms. Research Policy. 28(1): 63-80.

von Hippel, E. (1986). Lead users: a source of novel product concepts. Management Science, 32(7), 791-805.

von Hippel, E. (1990). Task partitioning: An innovation process variable. Research Policy, 19(5), 407-418.

von Hippel, E. (2005). Democratizing Innovation. MIT Press.

Williamson, O. E. (1991). Comparative economic organization: The analysis of discrete structural alternatives. Administrative Science Quarterly, 269-296. 
Table 1: Examples of innovations in sampled industries.

\begin{tabular}{|c|c|}
\hline Industry & Innovation \\
\hline Food & Antioxidant chocolates \\
\hline Food & Live active cheddar cheese with probiotics \\
\hline Beverage & vitamins enhanced flavoured spring water \\
\hline Textile & Heat resistant yarn \\
\hline Textile & New varieties of garments \\
\hline Paper & $\begin{array}{l}\text { Low surface energy light tapes resistant to air, water, detergents, moisture, } \\
\text { UV light, and dust }\end{array}$ \\
\hline Paper & Hanging folder with easy slide tab \\
\hline Petroleum & Non detergent motor oil \\
\hline Chemicals & BioSolvents - water based emulsion technology \\
\hline Pharmaceutical & Oral gallium to prevent bone decay \\
\hline Pharmaceutical & inhalation anaesthetics \\
\hline Plastics & Styrene based floor underlayment \\
\hline Minerals & Multi-wall polycarbonate recyclable panels \\
\hline Minerals & Solar glass and coating technologies solar modules \\
\hline Metals & Solder system \& nanofoils \\
\hline Metals & New water faucets and bath products \\
\hline Electronics & USB-to-GPIB Interface Adapter \\
\hline Electronics & 20-h IPS Alpha LCD Panel \\
\hline Semiconductors & Linear voltage regulators \\
\hline Semiconductors & Phase change memory \\
\hline Transport Equipment & Improved alcohol sensing system \\
\hline
\end{tabular}


Table 2. Rates of innovation and imitation, patenting and \% sales for U.S. mfg. industries.

\begin{tabular}{|c|c|c|c|c|c|c|}
\hline $\begin{array}{l}\text { INDUSTRY } \\
\text { (Number of } \\
\text { respondents) }\end{array}$ & $\begin{array}{c}\% \text { NOSI } \\
\mathbf{a}\end{array}$ & $\begin{array}{c}\% \text { NTM } \\
\text { b }\end{array}$ & $\begin{array}{c}\text { \%Imitator } \\
\text { a-b }\end{array}$ & $\begin{array}{c}\% \text { sales } \\
\text { from NOSI }\end{array}$ & $\begin{array}{l}\text { \% sales from } \\
\text { focal NTM } \\
\text { innovation }\end{array}$ & $\begin{array}{l}\% \text { NTM } \\
\text { patented }\end{array}$ \\
\hline & (1) & (2) & (3) & (4) & (5) & (6) \\
\hline Food/Bev (362) & $40 \%$ & $13 \%$ & $27 \%$ & $16 \%$ & $9 \%$ & $24 \%$ \\
\hline Textiles (210) & $37 \%$ & $15 \%$ & $22 \%$ & $19 \%$ & $15 \%$ & $51 \%$ \\
\hline Wood (385) & $33 \%$ & $8 \%$ & $25 \%$ & $15 \%$ & $7 \%$ & $11 \%$ \\
\hline Chemicals (365) & $49 \%$ & $24 \%$ & $25 \%$ & $17 \%$ & $9 \%$ & $42 \%$ \\
\hline Pharma (128) & $62 \%$ & $28 \%$ & $33 \%$ & $23 \%$ & $13 \%$ & $61 \%$ \\
\hline Plastics (340) & $47 \%$ & $16 \%$ & $31 \%$ & $14 \%$ & $6 \%$ & $42 \%$ \\
\hline Minerals (323) & $30 \%$ & $9 \%$ & $21 \%$ & $21 \%$ & $14 \%$ & $35 \%$ \\
\hline Metals (324) & $38 \%$ & $9 \%$ & $29 \%$ & $14 \%$ & $5 \%$ & $23 \%$ \\
\hline Fab Metals (424) & $38 \%$ & $10 \%$ & $28 \%$ & $28 \%$ & $8 \%$ & $35 \%$ \\
\hline Machinery (384) & $44 \%$ & $20 \%$ & $24 \%$ & $24 \%$ & $14 \%$ & $52 \%$ \\
\hline Electronics (146) & $76 \%$ & $33 \%$ & $43 \%$ & $38 \%$ & $9 \%$ & $58 \%$ \\
\hline Semicond (302) & $60 \%$ & $27 \%$ & $33 \%$ & $29 \%$ & $18 \%$ & $59 \%$ \\
\hline Instruments (135) & $59 \%$ & $37 \%$ & $22 \%$ & $17 \%$ & $7 \%$ & $54 \%$ \\
\hline Elec Equip (344) & $54 \%$ & $26 \%$ & $28 \%$ & $25 \%$ & $13 \%$ & $53 \%$ \\
\hline Transp (339) & $50 \%$ & $27 \%$ & $23 \%$ & $25 \%$ & $11 \%$ & $34 \%$ \\
\hline Med Equip (136) & $55 \%$ & $22 \%$ & $33 \%$ & $37 \%$ & $31 \%$ & $72 \%$ \\
\hline Misc. (510) & $47 \%$ & $19 \%$ & $29 \%$ & $30 \%$ & $10 \%$ & $45 \%$ \\
\hline All manuf. (5157) & $42 \%$ & $16 \%$ & $27 \%$ & $22 \%$ & $11 \%$ & $42 \%$ \\
\hline Large firms (1268) & $65 \%$ & $38 \%$ & $27 \%$ & $24 \%$ & $10 \%$ & $63 \%$ \\
\hline Med. firms(945) & $54 \%$ & $23 \%$ & $31 \%$ & $20 \%$ & $15 \%$ & $47 \%$ \\
\hline Small firms (2944) & $39 \%$ & $13 \%$ & $26 \%$ & $19 \%$ & $12 \%$ & $36 \%$ \\
\hline
\end{tabular}


Table 3: Sources of external invention, as \% of innovators, by industry and firm size.

\begin{tabular}{lccccccccc}
\hline & N & $\begin{array}{c}\text { Any } \\
\text { source } \\
\%\end{array}$ & $\begin{array}{c}\text { Supp- } \\
\text { lier } \\
\%\end{array}$ & $\begin{array}{c}\text { Custo- } \\
\text { mer } \\
\%\end{array}$ & $\begin{array}{c}\text { Other } \\
\text { firm in } \\
\text { Industry } \\
\%\end{array}$ & $\begin{array}{c}\text { Consult./ } \\
\text { Service } \\
\text { provider } \\
\%\end{array}$ & $\begin{array}{c}\text { Indep. } \\
\text { Inventor } \\
\%\end{array}$ & $\begin{array}{c}\text { Univ } \\
\%\end{array}$ & $\begin{array}{c}\text { Tech. } \\
\text { Special- } \\
\text { ist } \\
\%\end{array}$ \\
\hline Food \& Bev & 63 & 46 & 34 & 15 & 8 & 1 & 5 & 0 & 6 \\
Textiles & 33 & 50 & 32 & 26 & 4 & 3 & 6 & 0 & 9 \\
Wood & 52 & 52 & 22 & 27 & 11 & 14 & 1 & 0 & 15 \\
Chemicals & 102 & 49 & 17 & 15 & 5 & 10 & 3 & 5 & 16 \\
Pharma & 30 & 50 & 2 & 9 & 17 & 6 & 6 & 19 & 30 \\
Plastics & 74 & 53 & 11 & 28 & 5 & 11 & 16 & 4 & 27 \\
Minerals & 36 & 49 & 6 & 23 & 3 & 8 & 12 & 10 & 27 \\
Metals & 44 & 49 & 29 & 30 & 11 & 11 & 4 & 7 & 13 \\
Fab'd Metal & 60 & 48 & 10 & 38 & 6 & 0 & 4 & 3 & 7 \\
Machinery & 98 & 49 & 7 & 36 & 10 & 12 & 7 & 6 & 21 \\
Electronics & 50 & 45 & 11 & 17 & 10 & 8 & 6 & 5 & 14 \\
Semicond. & 91 & 62 & 16 & 49 & 9 & 13 & 8 & 9 & 23 \\
Instruments & 53 & 48 & 5 & 26 & 7 & 11 & 9 & 1 & 19 \\
Elect Equip & 98 & 44 & 12 & 26 & 4 & 8 & 7 & 4 & 17 \\
Transp. & 101 & 52 & 11 & 28 & 12 & 6 & 17 & 15 & 25 \\
Med Equip & 36 & 49 & 18 & 22 & 4 & 13 & 9 & 15 & 32 \\
Misc. & 106 & 46 & 8 & 20 & 13 & 10 & 9 & 2 & 18 \\
\hline All Mfg. & 1127 & 49 & 14 & 27 & 8 & 8 & 7 & 5 & 17 \\
\hline Large & 457 & 51 & 22 & 25 & 9 & 7 & 4 & 6 & 14 \\
Med & 224 & 48 & 12 & 26 & 9 & 8 & 4 & 5 & 16 \\
Small & 446 & 49 & 13 & 28 & 8 & 8 & 9 & 5 & 18 \\
\hline & & & & & & & & & \\
\end{tabular}


Table 4: Channels for acquiring inventions, as \% of innovators using external source.

\begin{tabular}{|c|c|c|c|c|c|c|c|c|}
\hline & $\mathrm{N}$ & $\begin{array}{c}\mathrm{M} \& \mathrm{~A} \\
\%\end{array}$ & $\begin{array}{c}\text { JV Coop } \\
\text { R\&D } \\
\%\end{array}$ & $\begin{array}{c}\text { License } \\
\%\end{array}$ & $\begin{array}{c}\text { Service } \\
\text { Contract } \\
\%\end{array}$ & $\begin{array}{c}\text { Informal } \\
\%\end{array}$ & $\begin{array}{c}\text { Market } \\
\%\end{array}$ & $\begin{array}{c}\text { Market } \\
\text { only } \\
\% \\
\end{array}$ \\
\hline Food/Bev & 26 & 11 & 73 & 17 & 20 & 15 & 32 & 17 \\
\hline Textiles & 10 & 7 & 76 & 20 & 17 & 9 & 34 & 16 \\
\hline Wood & 23 & 12 & 54 & 5 & 45 & 32 & 50 & 15 \\
\hline Chemicals & 38 & 6 & 67 & 5 & 35 & 29 & 44 & 18 \\
\hline Pharma & 13 & 39 & 40 & 56 & 8 & 17 & 82 & 43 \\
\hline Plastics & 32 & 25 & 61 & 9 & 27 & 36 & 45 & 13 \\
\hline Minerals & 15 & 13 & 69 & 12 & 11 & 56 & 36 & 17 \\
\hline Metals & 14 & 19 & 64 & 3 & 17 & 46 & 39 & 18 \\
\hline Fab'd Metals & 22 & 0 & 58 & 9 & 5 & 72 & 14 & 0 \\
\hline Machinery & 35 & 11 & 53 & 6 & 17 & 42 & 34 & 22 \\
\hline Electronics & 19 & 5 & 83 & 3 & 19 & 12 & 22 & 3 \\
\hline Semicond. & 37 & 15 & 64 & 15 & 30 & 43 & 37 & 16 \\
\hline Instruments & 19 & 6 & 41 & 42 & 14 & 14 & 60 & 45 \\
\hline Elect -Equip & 27 & 19 & 62 & 21 & 36 & 42 & 55 & 22 \\
\hline Transp. & 37 & 11 & 67 & 33 & 18 & 21 & 53 & 29 \\
\hline Med Equip & 13 & 15 & 45 & 17 & 30 & 31 & 57 & 24 \\
\hline Miscl & 43 & 3 & 63 & 13 & 20 & 33 & 33 & 14 \\
\hline All Manuf & 423 & 10 & 61 & 13 & 21 & 37 & 37 & 16 \\
\hline Large firms & 173 & 18 & 53 & 21 & 21 & 29 & 47 & 24 \\
\hline Med firms & 80 & 13 & 66 & 10 & 17 & 27 & 36 & 19 \\
\hline Small firms & 170 & 8 & 60 & 13 & 23 & 41 & 36 & 14 \\
\hline
\end{tabular}

Notes: Channels are not mutually exclusive. Market channels consist of licensing, contracts or M\&A. 
Table 5a: Value of inventions by source: \% business unit sales from focal invention (The reference category for all specifications is internal invention.). OLS regressions.

\begin{tabular}{|c|c|c|c|c|}
\hline & $\begin{array}{l}\text { Log of \% BU } \\
\text { sales from focal } \\
\text { innovation }\end{array}$ & $\begin{array}{l}\text { (\% BU sales } \\
\text { from focal } \\
\text { innovation } \\
\text { greater than } \\
50 \%)=1 \\
(2)\end{array}$ & $\begin{array}{l}\text { Log of \% BU } \\
\text { sales from focal } \\
\text { innovation } \\
\text { (Sample } \\
\text { Selection } \\
\text { correction) } \\
(3)\end{array}$ & $\begin{array}{l}\text { (\% BU sales from } \\
\text { focal innovation } \\
\text { greater than } 50 \%) \\
=1 \text { (Sample } \\
\text { Selection } \\
\text { correction) } \\
(4)\end{array}$ \\
\hline Customer & $-0.17 * *(0.07)$ & $-0.06 * * *(0.02)$ & $-0.19 * *(0.07)$ & $-0.07 * * *(0.02)$ \\
\hline Supplier & $0.07(0.09)$ & $0.06 * *(0.03)$ & $0.03(0.10)$ & $0.05 *(0.03)$ \\
\hline Other Firm & $-0.09(0.11)$ & $-0.03(0.03)$ & $-0.13(0.12)$ & $-0.04(0.04)$ \\
\hline Specialists & $0.36 * * *(0.09)$ & $0.07 * * *(0.03)$ & $0.34 * * *(0.09)$ & $0.07 * *(0.03)$ \\
\hline Ln (BU Empl) & $-0.32 * * *(0.06)$ & $-0.07 * * *(0.02)$ & $-0.32 * * *(0.06)$ & $-0.07 * * *(0.02)$ \\
\hline R\&D & $0.43 * * *(0.14)$ & $0.09 * *(0.04)$ & $0.43 * * *(0.14)$ & $0.09 * *(0.04)$ \\
\hline Ind. FE's (45) & Yes & Yes & Yes & Yes \\
\hline Controls & Parent size, Age & Parent size, Age & Parent size, Age & Parent size, Age \\
\hline $\begin{array}{l}\text { Ln (share of } \\
\text { source) }\end{array}$ & & & $-0.05(0.07)$ & $-0.01(0.02)$ \\
\hline $\mathbf{N}$ & 927 & 927 & 927 & 927 \\
\hline $\mathbf{R}^{2}$ & 0.19 & 0.15 & 0.19 & 0.15 \\
\hline
\end{tabular}

Notes: The dependent variable in Columns $1 \& 3$ is the $\%$ sales from focal innovation. The dependent variable in Columns 2 and 4 is a binary variable taking value 1 if the sales from the focal innovation exceed $50 \%$ of total firm sales, and 0 otherwise. Standard errors in parentheses. Standard errors are in parentheses. ${ }^{*} \mathrm{p}<.10,{ }^{* *} \mathrm{p}<.05$, $* * * \mathrm{p}<.01$ 
Table 5b: Value of inventions by source: Other indicators (The reference category for all specifications is internal invention.) OLS regression, all with sample selection correction.

\begin{tabular}{|c|c|c|c|c|}
\hline & $\begin{array}{l}\text { Innovator invests } \\
\text { equip or skills = } 1 \\
\text { (1) }\end{array}$ & $\begin{array}{l}\text { Innovator } \\
\text { invests in sales } \\
\text { channel =1 } \\
(2) \\
\end{array}$ & $\begin{array}{l}\text { Innovator patents } \\
\text { focal innovation=1 } \\
\text { (3) }\end{array}$ & $\begin{array}{l}\text { Innovator } \\
\text { increased market } \\
\text { share=1 } \\
\text { (4) }\end{array}$ \\
\hline Customer & $-0.04(0.04)$ & $0.00(0.04)$ & $-0.08 * *(0.03)$ & $-0.05(0.04)$ \\
\hline Supplier & $-0.19 * * *(0.05)$ & $0.01(0.05)$ & $-0.11 * *(0.05)$ & $0.07(0.05)$ \\
\hline Other Firm & $0.00(0.06)$ & $0.02(0.06)$ & $-0.08(0.06)$ & $-0.06(0.06)$ \\
\hline Specialists & $0.14 * * *(0.05)$ & $0.10 * *(0.04)$ & $0.28 * * *(0.04)$ & $0.14 * * *(0.05)$ \\
\hline Ln (Empl) & $0.06 *(0.03)$ & $0.05 *(0.03)$ & $0.11 * * *(0.03)$ & $0.03(0.03)$ \\
\hline R\&D & $-0.02(0.07)$ & $-0.03(0.07)$ & $0.18 * * *(0.06)$ & $0.16 * *(0.07)$ \\
\hline $\begin{array}{l}\text { Ln (share of } \\
\text { source) }\end{array}$ & $-0.08 * *(0.03)$ & $-0.02(0.03)$ & $0.03(0.03)$ & $-0.03(0.03)$ \\
\hline Ind. FE's (45) & Yes & Yes & Yes & Yes \\
\hline $\mathbf{N}$ & 1012 & 1017 & 1019 & 916 \\
\hline $\mathbf{R}^{2}$ & 0.14 & 0.16 & 0.26 & 0.13 \\
\hline
\end{tabular}

Notes: All specifications include a sample selection correction and control for parent size and age. Standard errors are in parentheses. ${ }^{*} \mathrm{p}<.10, * * \mathrm{p}<.05, * * * \mathrm{p}<.01$ 
TABLE 6: Contribution to innovation by external source (\% reduction in innovation rate if the source were not available).

\begin{tabular}{ll}
\hline Source & Contribution \\
\hline Customer & $18.9 \%(1.44)$ \\
Supplier & $8.5 \%(1.06)$ \\
Other Firm & $4.6 \%(0.69)$ \\
Specialist & $10.3 \%(0.95)$ \\
All external & $44.6 \%(2.06)$ \\
Internal & $47.2 \%(2.07)$ \\
\hline
\end{tabular}

Notes: Bootstrap standard errors in parentheses based on 500 draws. Contribution to innovation calculated as: [ $\mathrm{P}_{0}$ $\left./\left(1-\mathrm{P}_{0}\right)\right]\left[\left(\mathrm{P}_{\mathrm{i}}\right) /\left(1-\mathrm{P}_{\mathrm{i}}\right)\right]$, where $1-\mathrm{P}_{0}=\%$ innovators, $\mathrm{P}_{i}=$ Share of inventions from source $i$. 


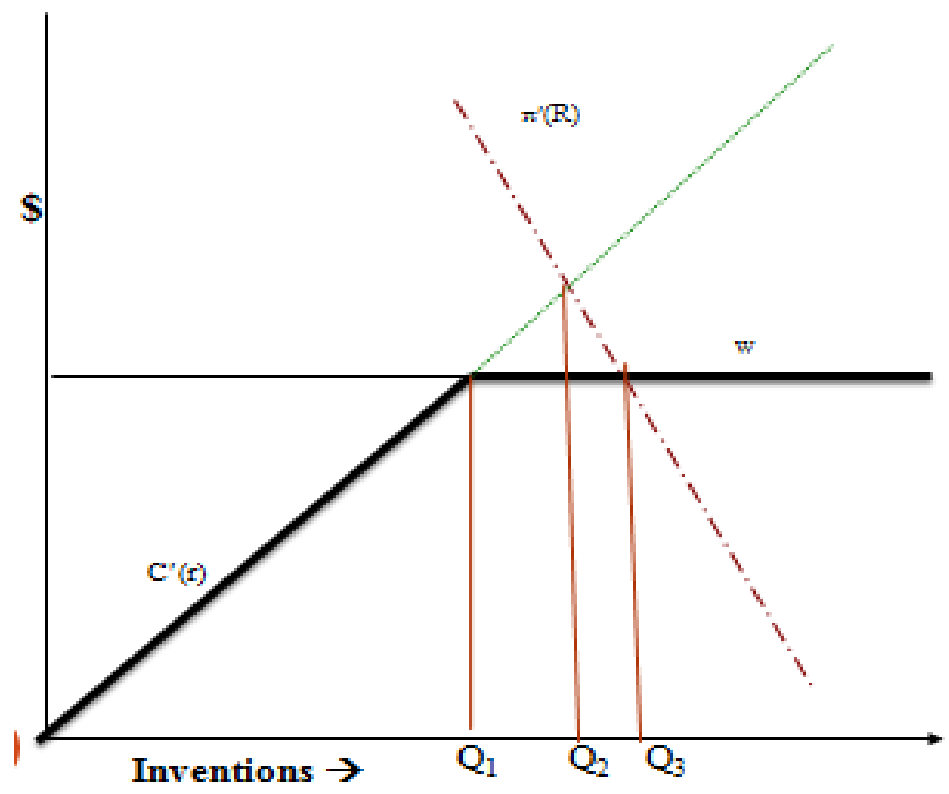

Figure 1: Supply and Demand for Inventions. 


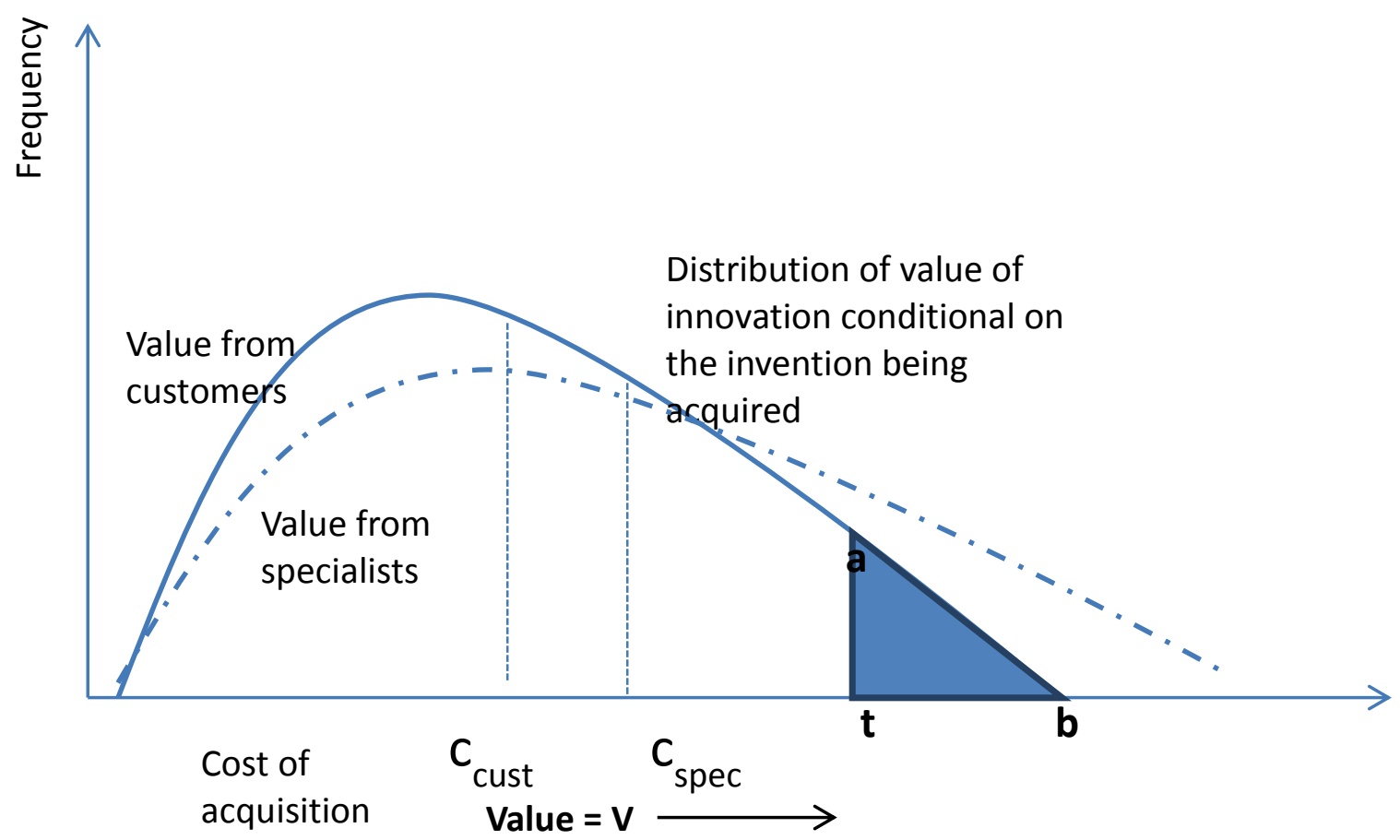

Figure 2. Value and cost of acquisition of customer and specialist sourced inventions. 


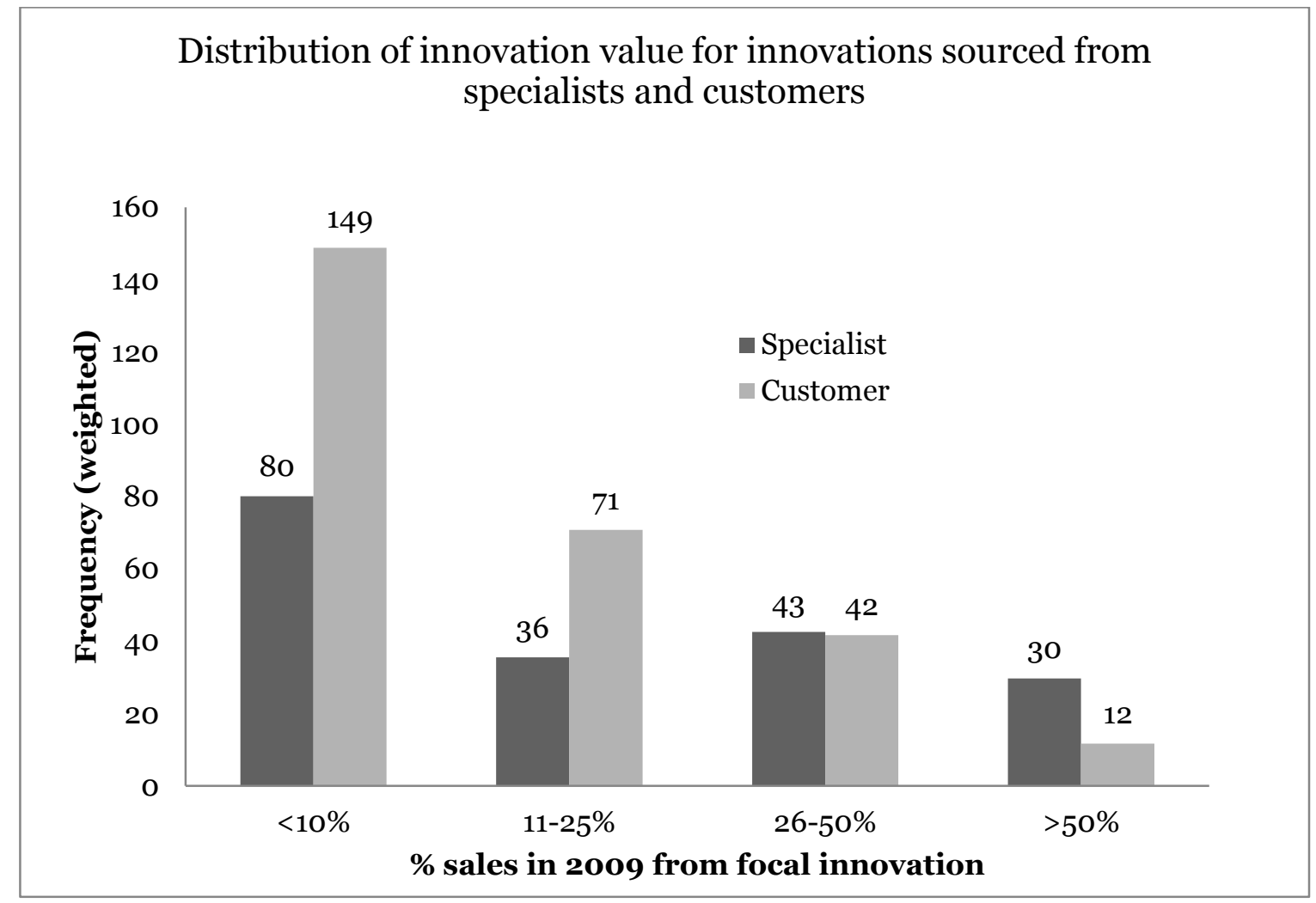

Figure 3. Frequency distribution of customer and specialist sourced innovation by \% sales from the focal innovation. 